\title{
Quantitative analysis of litter-fall in hornbeam-oak-pine stands in the Lviv Roztoche region
}

\author{
Olga Krynytska ${ }^{1}$, Taras Bondarenko ${ }^{2}$, Jozef Capuliak ${ }^{3,5}$, Marek Trenčiansky $^{4 *}$ \\ ${ }^{1}$ Ukrainian National Forestry University, Henerala Chuprynky St, 103, 79000 Lviv, Ukrajine \\ ${ }^{2}$ Maria Curie-Sklodowska University, Plac Marii Curie-Skłodowskiej 5, 20-031 Lublin, Poland \\ ${ }^{3}$ National Forest Centre - Forest Research Institute Zvolen, T. G. Masaryka 2175/22, SK - 96092 Zvolen, Slovak Republic \\ ${ }^{4}$ Technical University in Zvolen, T. G. Masaryka 24, SK - 96053 Zvolen, Slovak Republic \\ ${ }^{5}$ Czech University of Life Sciences Prague, Faculty of Forestry and Wood Sciences, Kamýcká 129, \\ CZ - 16521 Praha 6 - Suchdol, Czech Republic
}

\begin{abstract}
The aim of the article is to find out if there is a difference between amount of litter-fall in hornbeam-oak-pine stands according to regeneration (naturallyand artificially) and age of the stand (middle-aged, mature). We analysed the annual dynamics of litter-fall (litter) and its fractions (needles of Scots pine; leaves of common oak; leaves of associate species; twigs; bark; pine cones; acorns of common oak; seeds of other species; acorn cups, winged seeds; lichens, mosses) in middle-aged hornbeam-oak-pine stands which were regenerated naturally or artificially on the cutover sites following two-stage uniform shelterwood felling and clearcutting, as well as in a mature parent stand (control plot) in the Lviv Roztoche region. Two peaks of organic matter fall have been revealed on both the control plot and the experimental plots: the largest one in October and much lower in May. It was found that the annual mass of litter was 5.8 - 6.6 tons per hectare, the annual weight of litter in the middle-aged hornbeam-oak-pine stands was greater than in the mature stands. Annual dynamics of certain fractions of litter in the stands is preconditioned by the specificity of functioning of the relevant bodies of the trees.
\end{abstract}

Key words: hornbeam-oak-pine stands; natural and artificial forest; mass of litter; fractions of litter; annual dynamics

Editor: Jiří Novák

\section{Introduction}

The litter-fall of forest stands substantially affects the structure of forest floor, biotic cycling of mineral elements, intensity of mineralization of the dead organic residues and the composition of mineralization products (Bodnar 2007; Bodnar 2000; Bublinec 1994; Fischer \& Binkley 2000; Gorshenin \& Shvydenko 1977; Kremenetska 2000; Lukac \& Godbold 2011; Melehov 1980; Novák et al. 2013; Pogrebnyak 1968; Rybak 2004). It is found that the mass of litter in forest stands varies significantly. It depends on many factors: forest stand composition and productivity, the presence of other components of forest stands (underbrush, advance growth, and grass cover), the number of vertebrate and invertebrate animals, climatic and soil-hydrological conditions, weather conditions, etc. (Gorshenin 1977; Kacálek et al. 2013; Novák et al. 2014, 2015; Kovalevskyi 1952; Melehov 1980; Pogrebnyak 1968, ICP Forest 2005).
The amount of litter-fall is related to these climate-soil factors, as the total mass of litter is directly proportional to the fertility of the soil. Through its effects on ground vegetation, litterfall is also closely related to biodiversity issues. This research tests the following hypotheses:

1. In the Lviv Roztoche region is the difference between the litter-fall in naturally and artificially regenerated hornbeam-oak-pine stands.

2. In the Lviv Roztoche region is the difference between the litter-fall in naturally and artificially regenerated (middle-aged) and mature (old) hornbeam-oak-pine stand.

The objective of the study was to reveal the peculiarities of annual dynamics of litter-fall, its fractional composition in middle-aged and mature hornbeam-oak-pine stands regenerated naturally or artificially in Lviv Roztoche area and its comparison to findings in other temperate forests in Europe. 


\section{Material and methods}

The objects of the research were the hornbeam-oak-pine forest stands of natural and artificial origin formed after the harvest cutting in the research and production permanent area of the Department of Forestry, Ukrainian National Forestry University (UNFU). The permanent study area was established in 1962-1963 under the supervision of prof. M. Gorshenin (Gorshenin 1972) in the hornbeam-oak-pine stand of the Stradch Production and Training Center of UNFU.

The type of forest (Pogrebnyak 1955): moist fresh hornbeam-pine fairly fertile oak forest type, the type of soil: soddy low-podzolic loamy sand on the sands of glacial and eluvium origin (Pieshko 1972). The composition of the stand before cutting: $70 \%$ of Pinus sylvestris, $30 \%$ of Quercus robur and folowed individual trees: Carpinus betulus, Picea abies, Acerplatanoides, Tilia cordata, Fagus sylvatica. The age of forest: $70-80$ years, relative stand density: $0.9-1.0$, stand volume: $380-440 \mathrm{~m}^{3} \mathrm{ha}^{-1}$ (Gorshenin 1972).

The study was performed in three experimental sections of the permanent study area: section SC: a two-stage uniform shelterwood felling was carried out (first cut in 1962-1963, the second one in 1967-1968); section CC: clearcutting was carried out in 1962-1963,and the control section C: no felling of the forest was conducted.

In section SC, the forest stand was based on natural regeneration of Scots pine (Pinus sylvestris L.), common oak (Quercus robur L.), hornbeam (Carpinus betulus L.) and other species. In section CC following timber cutting in 1962, a forest plantation was established according to the scheme $50 \%$ of Scots pine, $50 \%$ common oak. Two year old seedlings of pine and oak were planted in rows. The row spacing was $2 \mathrm{~m}$, the plant spacing was $0.5 \mathrm{~m}$. Hornbeam and other species were regenerated naturally. Forest inventory characteristics of the forest stands in the sections are presented in Table 1.

The share of tree species was calculated according to basal area. Canopy density was estimated as the ratio of the area of horizontal projections tree crowns (excluding the area of overlap) to the total area of the stand.

As can be seen from Table 1, 53-56 year old highly productiveforest stands got established in the experimental sections SC and CC dominatedby Scots pine, witha significant share of common oak, and mixture of hornbeam and other species.

The artificially regenerated forest stand, in comparison to naturally regenerated, is characterised by a markedly higher productivity of Scots pine, common oak and common hornbeam, as well as significantly greater volume of wood. The control section $\mathrm{C}$ has preserved a highly productive stand $120-130$ years of age which is dominated by pine. However, its share in the stand has been gradually decreasing as pine trees of more than a hundred year old are often affected by plant diseases resulting in pine decline.

Auxiliary species in the sections of the permanent study area also participate in the formation of litter. Their participation in the litter-fall of dead organic matter can be quite significant. Thus, according to N. Remezov's research (1953), the undergrowth of hazel (Corylus avellana L.) increased the weight of litter by 0.9 tons per hectare and thickets of yellow acacia (Caragana arborescens Zam.) - up to 4 tons per hectare.

In the control section $C$, where the total stand canopy density is $0.80-0.85$ and the age of forest stand is more than 100 years, the undergrowth is well developed. Its density is 0.4 ; the composition is dominated by common hazel, the height of bushes reaching $6-8$ (10) m. Common in the section are also bird cherry tree (Padus avium Mill.) and rowan tree (Sorbus aucuparia L.), with occasional spindle tree warty (Euonymus verrucosa Scop.) and haw tree (Crataegus monogyna Jacq.).

In the experimental sections of the permanent study area, in contrast to the control section, the undergrowth began to emerge relatively recently and yet it is underdeveloped.

Table 1. Forest inventory indices of the forest stands in the sections of the permanent study area, 2015.

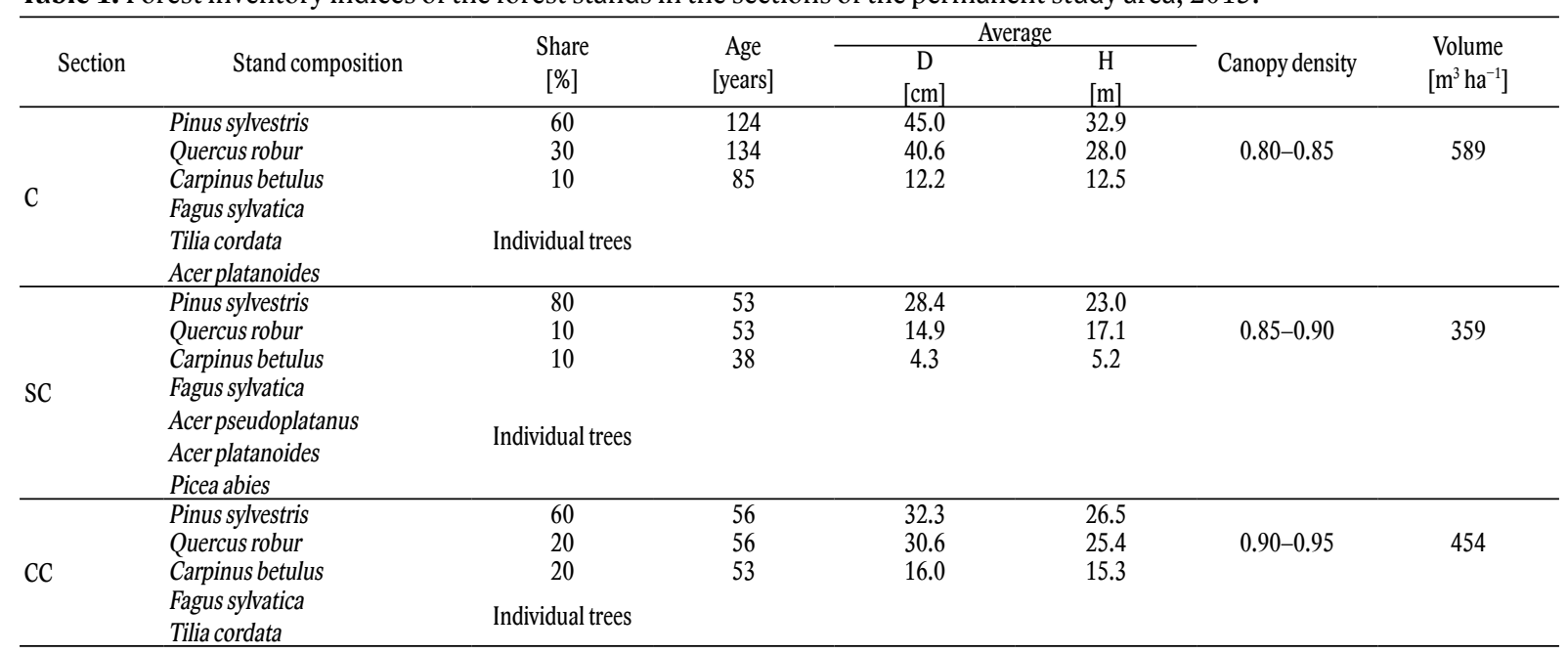


In section $\mathrm{SC}$, whose stand was regenerated naturally, the canopy density of tree species is $0.85-0.90$. The undergrowth is sparse, its canopy density being 0.1 -0.2 . Its composition is dominated by common hazel (the height of shrubs is $1-5 \mathrm{~m}$ ) with occasional rowan trees, bird cherry tree and buckthorn alder (Frangula alnus Mill.).

Stand canopy density in section CC is $0.9-0.95$. The undergrowth is almost absent, there are only a few instances of common hazel (the height being up to $1 \mathrm{~m}$ ) and spindle tree warty (the height is $0.5 \mathrm{~m}$ ).

To determine forest inventory indices of the sections' stands, sample plots (size of plot - 1 ha) were established according to the common forest inventory technique (Sokolova 1984). The stock of the tree species was determined by using the guidelines of works (Shvydenko 1987; Nikitin 1984). The age of the trees was estimated by using the increment cores of wood technique, adjusted to the height of the cores extraction.

To study the annual dynamics of litter-fall, litter collectors (traps) were used of size $1 \times 1 \mathrm{~m}$ installed in geometric order in each section in 12-fold repetition. Litter collectors were the crates with a side height of $15 \mathrm{~cm}$ and a mesh $(4 \times 4 \mathrm{~mm})$ down. The top edge of skirting litter collectors located at a height of $0.6 \mathrm{~m}$. above the ground. The working area of each litter collectors was $1 \mathrm{~m}^{2}$. Separate samples of raw litter-fall collected from litter collectors on each section were combined into one (mixed) sample.Mass of litter-fall was calculated from mixed sample $\left(12 \mathrm{~m}^{2}\right)$ per hectare. The litter from the collectors was taken on the last day of each month (for the DecemberMarch period - total in March). For maintaining equidistant distance we divided sum of litter-fall in December-March proportionally to each month in the analyzed period. In the laboratory, the litter was divided into fractions: 1 - needles of Scots pine (Fig. 2);2-common oak leaves (Fig. 3); 3 - leaves of the other (associate) species (Fig. 4); 4-twigs (Fig. 5); 5-bark (Fig. 6); 6-cones of Scots pine; 7 - acorns of common oak; 8 - seeds of other species; 9 - acorn cups, winged seeds; 10 - lichens, mosses. The litter fractions were oven-dried. For each analyzed fractions according to the sections (Fig. 1-6), we calculated the following statistical indicators: Average, Standard deviation, Minimum, Maximum, and Median.

\section{Results and discussion}

The analysis of the field materials showed that an accumulated amount of litter-fall was larger in the middle-aged stands than in the mature ones in the hornbe- am-oak-pine stands of the Lviv Roztoche within a year period (Table 2).

Comparable litter production (up to 7 tons per hectar) in mixed oak stands was also marked by Gursky (1952); Kovalevsky (1952); Gorshenin \& Shvidenko (1977); Nakonechny (1978) and Ostapchuk (2012) in other forest areas. According to Bondar (2007), the annual mass of litter in pine-oak stands of fresh fairly fertile site type of Central Polissia of Ukraine is about 5.2 tons per hectare. In young oak stands in the Czech Republic fell around 4 tons of dry mass per hectare (Novak et al. 2014) and in young pine stands also about 4 tons per hectare (Novak et al. 2015).

The litter-fall in the stands is a continuous process, but its intensity changes depending on the months of the year. In general, according to Gorshenin \& Shvidenko (1977), the autumn litter-fallofdead organic matter amounts to $68-72 \%$, winter and spring: $20-23 \%$, and in summer: $6-9 \%$.

As it can be seen from Table 2, two peaks can be observed in the annual dynamics of litter-fall in hornbeam-oak-pine forest stands in Roztoche: the highest is in October (in section $\mathrm{C}$ the litter-fall was $38.1 \%$ of all the litter, in section SC: $26.1 \%$, in CC: $36.9 \%)$ and one lower peak was observed in May(12.9\%; 14.4\%; 16.1\%and $10.6 \% ; 9.8 \% ; 15.4 \%$, respectively, of the annual litter see Table 2, Fig. 1). Very similar finding was reported also by Monitoring of ICP Forests plots in spruce, beech, fir forest stand in central Carpatian (Pavlenda \& Pajtík $\&$ Priwitzer et al. 2012).

On the whole, during the autumn months, section $\mathrm{C}$ had $61.3 \%$ of the annual litter, section SC: $53.6 \%$, CC: $54.1 \%$; during the winter and spring months in section C fell $25.7 \%$ of the litter,SC: $28.1 \%$, CC had $33.9 \%$; during the summer months in section $\mathrm{C}$ fell $13.0 \%$ of the litter, SC: $18.3 \%$, and CC: up to $12.0 \%$.

The least amount of litter was seen in April (in section C: $2.2 \%$, SC: $3.9 \%$, CC: $2.4 \%$ ). Small amount of litter was observed in July (section C: $2.9 \%$, SC: $5.5 \%$, CC: 4.2\%), in August ( section CO: 5.4\%,SC: $5.3 \%$, CC: $3.0 \%$ ) and in November (section C: $7.6 \%$, SC: $7.0 \%$, CC: $7.3 \%$ - see Fig. 1).

The analysis of the fractional composition of the litter revealed the following regularities. The largest share of litter accounts for the needles and leaves: in section C: $64.3 \%$, SC: $54.8 \%$, CC: $61.3 \%$ (Table 3). Next, in order of decreasing, fractions are arranged as follows: twigs (section C: $12.8 \%$, SC: $21.3 \%$, CC: $17.3 \%$ ), cones (section C: $11.2 \%$, SC: $14.5 \%$, CC: $11.8 \%$ ), bark (section C: $8.5 \%$, SC: $9.2 \%$, CC: $7.6 \%$ ), acorn cups, winged seeds (section C: $1.2 \%$, SC: $0.1 \%$, CC: $0.4 \%$ ), seeds of other species (sec-

Table 2. Monthly and annual mass of litter in the sections of the permanent study area, $\mathrm{kg} \mathrm{ha}^{-1}$.

\begin{tabular}{lccccccccccccc}
\hline \multirow{2}{*}{ Section } & \multicolumn{9}{c}{2013} & \multicolumn{1}{c}{ Total for } \\
\cline { 2 - 13 } & VIII & IX & X & XI & XII & I & II & III & IV & V & VI & VII \\
the year
\end{tabular}


tion $\mathrm{C}: 1.7 \%$, SC: $0.1 \%, \mathrm{CC}: 1.6 \%)$, lichens and mosses (section C: $0.24 \%$, SC: $0.03 \%$, CC: $0.04 \%$ ), acorns of common oak (section C: $0.07 \%$, SC: $0.02 \%$, CC: $0.02 \%$ ).

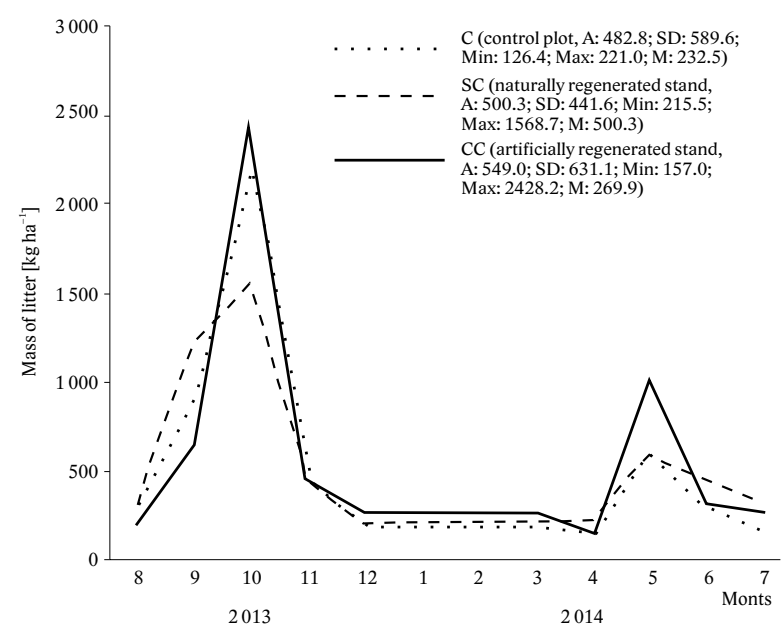

Fig. 1. Annual dynamics of the mass of litter in the sections of the permanent study area. (A: Average, SD: Standard deviation, Min: Minimum, Max: Maximum, M: median).

Similar data are shown in the works by Remezov (1953), Pogrebnyak (1968) and Gorshenin \& Shvidenko (1977). In particular, Kremenetska (2000) indicates that in the green belt of Kiev in pine-oak stands with domination of oak, the fraction of needles and leaves is $54-79 \%$ and with domination of pine is $44-64 \%$; a significant proportion falls also on the fraction of twigs ( $31-34 \%)$.

It should be noted that the studies also shows that the mass of certain fractions of litter is significantly dependent on the composition of forest stands. Thus, in section SC, most clearly dominated by pine, the proportion of needles in the litter-fall is the highest among all of the sections. Accordingly, section $\mathrm{C}$ is distinguished for the highest proportion of oak leaves, while sectionCC has the largest proportion of leaves of associate species (Table 3 ).

Table 3. Annual mass of the litter fractions in the sections of the permanent study area, $\mathrm{kg} \mathrm{ha}^{-1}$.

\begin{tabular}{lcccccc}
\hline \multirow{2}{*}{ Litter fractions } & \multicolumn{6}{c}{ Sections } \\
\cline { 2 - 7 } & \multicolumn{3}{c}{$\mathrm{C}$} & \multicolumn{2}{c}{$\mathrm{SC}$} & \multicolumn{2}{c}{$\mathrm{CC}$} \\
& {$\left[\mathrm{kg} \mathrm{ha}^{-1}\right]$} & {$[\%]$} & {$\left[\mathrm{kg} \mathrm{ha}^{-1}\right]$} & {$[\%]$} & {$\left[\mathrm{kg} \mathrm{ha}^{-1}\right]$} & {$[\%]$} \\
\hline Needles of Scots pine & 1505.8 & 25,99 & 2089.9 & 36,07 & 1831.6 & 31,61 \\
Leaves of common oak & 1111.3 & 19,18 & 750.3 & 12,95 & 732.3 & 12,64 \\
Leaves of other species & 1105.9 & 19,09 & 447.5 & 7,72 & 1472.7 & 25,42 \\
Twigs & 742.9 & 12,82 & 1278.4 & 22,06 & 1136.9 & 19,62 \\
Bark & 492.2 & 8,49 & 551.1 & 9,51 & 502.3 & 8,67 \\
Pine cones & 651.4 & 11,24 & 869.5 & 15,01 & 777.0 & 13,41 \\
Common oak acorns & 3.9 & 0,07 & 1.0 & 0,02 & 1.6 & 0,03 \\
Seeds of other species & 98.8 & 1,71 & 8.0 & 0,14 & 102.1 & 1,76 \\
Acorn cups, winged seeds & 68.0 & 1,17 & 6.7 & 0,12 & 29.0 & 0,50 \\
Lichens, mosses & 13.8 & 0,24 & 1.6 & 0,03 & 2.6 & 0,04 \\
\hline
\end{tabular}

The annual dynamics of individual fractions of litter in the stands is due to the specific functioning of respective bodies of the trees (Figs. 2-6).

Thus, the maximum fall of pine needles in the mature stands (section C) is observed in September (35.1\%), while in the middle-aged stands (sections SC and CC) - in
September and October (29.1\% and 36.0\%, respectively) - Fig. 2. The least amount of needles falls off in April (in section C: $1.5 \%$, SC: $1.0 \%$, CC: $1.1 \%$ ), followed by a slight increase in May - August. The needles in the artificially regenerated stand last longer than in mature stand and naturally regenerated stand.

The annual dynamics of the mass of leaf litter of common oak and the mass of leaf litter of associate species are almost identical (Fig. 3 and 4). The greatest amount of common oak leaves in all sections falls off in October (in section C: $85.4 \%$ of all oak leaf litter, SC: $81.8 \%$, CC: 83.1\%) and minimum - in April (section C: $0.1 \%$, SC: $0.2 \%$, CC: $0.05 \%$.

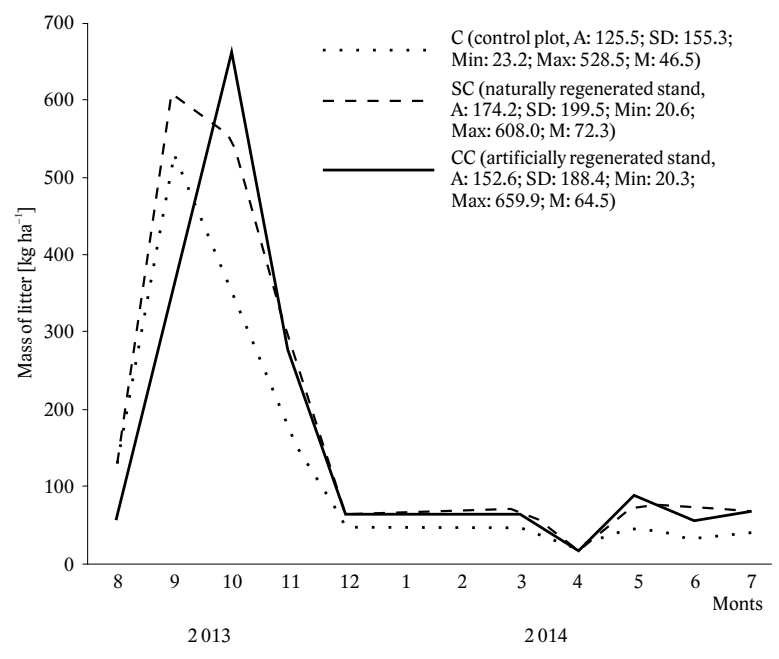

Fig. 2. Annual dynamics of the mass of needle litter in the sections of the permanent study area (A: Average, SD: Standard deviation, Min: Minimum, Max: Maximum, M: median).

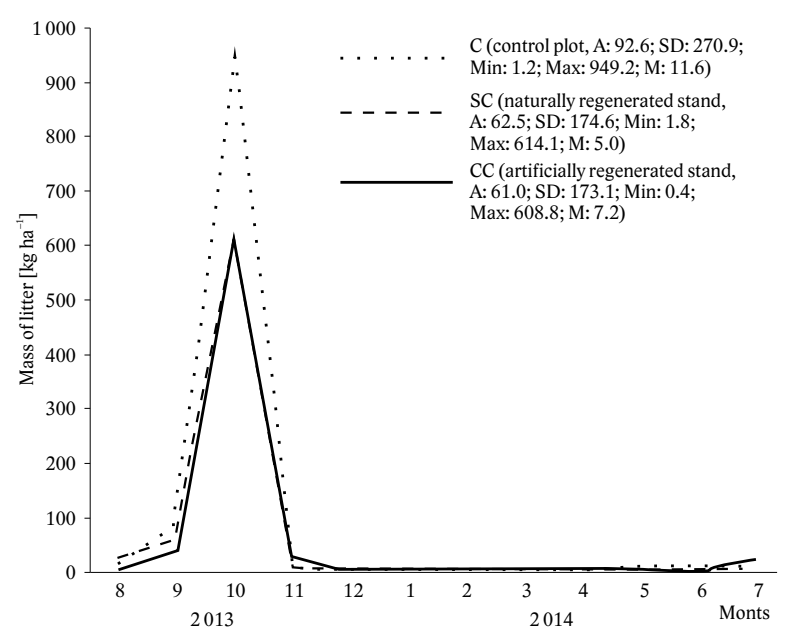

Fig. 3. Annual dynamics of the mass of common oak litter in the sections of the permanent study area (A: Average, SD: Standard deviation, Min: Minimum, Max: Maximum, M: median).

In the annual dynamics of the mass of leaf litter of associate species, in addition to the maximumin October (in section C: $67.2 \%$ of the annual litter, SC: $78.4 \%$, CC: $71.8 \%$ ), there was a slight increase in May (in sec- 
tion C: $11.2 \%$, SC: $5.5 \%$, CC: $9.4 \%)$. The second maximum is associated with the damage of young leaves, in particular of hornbeam, by insect pests.

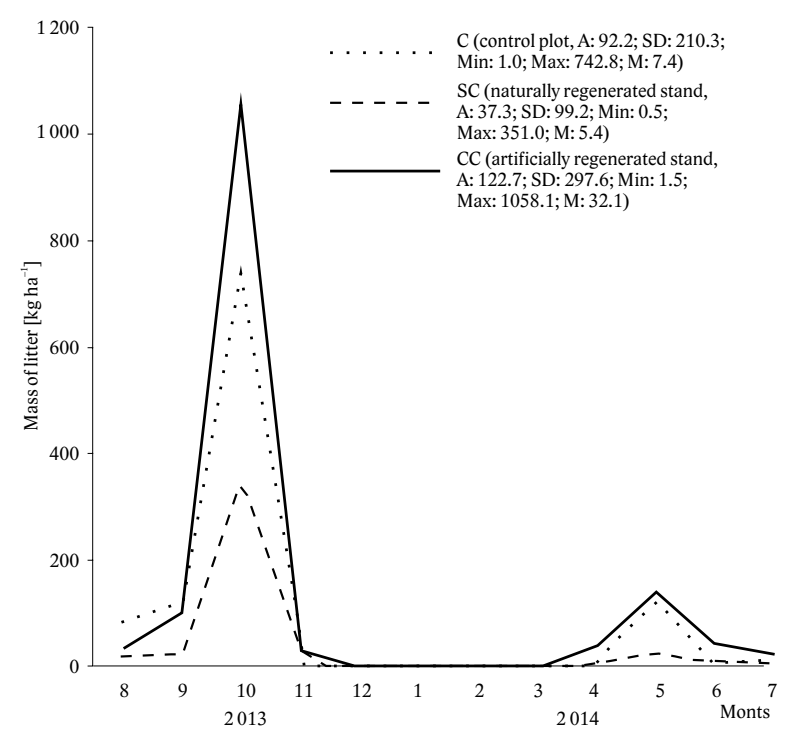

Fig. 4. Annual dynamics of the mass of associated woody species leaf litter in the sections of the permanent study area area (A: Average, SD: Standard deviation, Min: Minimum, Max: Maximum, M: median).

Annual dynamics of twig fall is quite different from the dynamics of the falling of needles and leaves. In the annual dynamics of the mass of the twig litter, the same maximum for all sections was only observed in winter (December-March: in section C: $34.8 \%$ of the annual litter, SC: $21.7 \%$, CC: $42.4 \%)$. In addition, one more maximum was observed in sections $\mathrm{C}$ and $\mathrm{CC}$ in May, and in section SC in September (Fig. 5). These peaks could be due to local wind action.

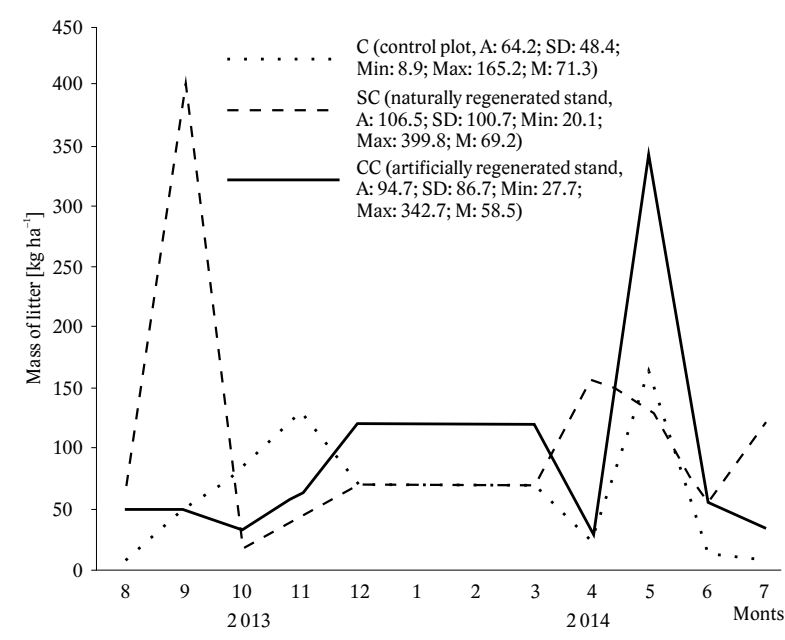

Fig. 5. Annual dynamics of the mass of twig litter in the sections of the permanent study area (A: Average, SD: Standard deviation, Min: Minimum, Max: Maximum, M: median).

In the annual dynamics of the mass of bark litter in all of the sections, there was observed one significant maxi- mum in winter months (section C: $33.3 \%$ of the annual litter, SC: $34.3 \%$, CC: $31.4 \%$ ) and two small peaks: in September (section C: $12.4 \%$, SC: $11.4 \%$, CC: $10.9 \%$ )and in May (section C: $11.4 \%$, SC: $11.1 \%$, CC: $15.2 \%$ ); in October, April and June, minimums were observed (Fig. 6).

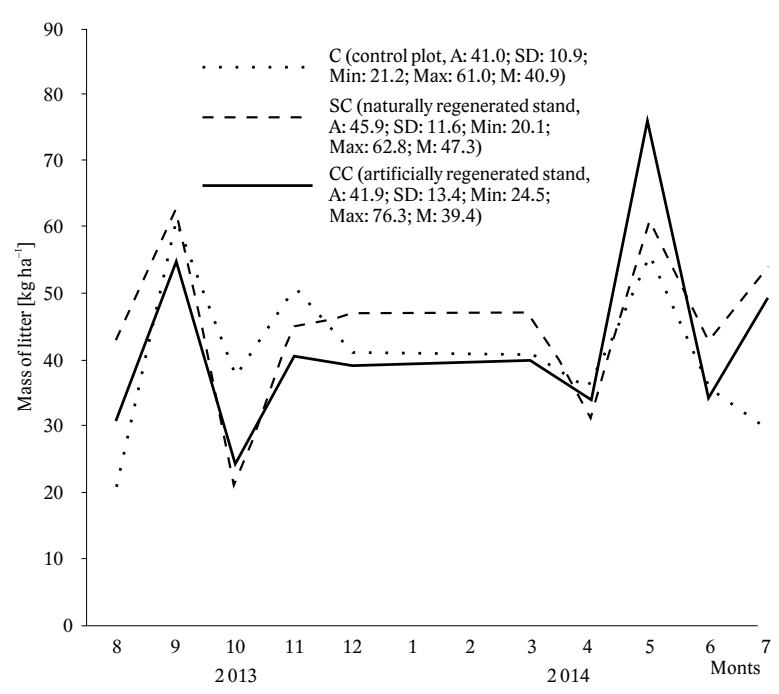

Fig. 6. Annual dynamics of the mass of bark litter in the sections of the permanent study area (A: Average, SD: Standard deviation, Min: Minimum, Max: Maximum, M: median).

The maximum of cone falling in all of the sections was observed in May. In sections SC, where the proportion of pine in the growing stock is the largest, the most significant cone falling occurred in June.

The fall of acorns of common oak was recorded only in August and September (there was hardly any crop). The bulk of seeds of other species was falling from September to April of the following year.

The litter-fall of lichens and mosses in all of the sections reached its maximum in December - March. Acorn cups were falling mainly in October - March.

Based on cumulative value of litter-fall in each section (Table 3) and statistical indicators (Figs. 2-6) we can confirm the difference between mature and middle age stands and as well as between artificially and naturally regenerated stands. Total mass of litter-fall is the highest in artificially regenerated stand $\left(6588 \mathrm{~kg} \mathrm{ha}^{-1}\right)$, then in naturally regenerated stand $\left(6004 \mathrm{~kg} \mathrm{ha}^{-1}\right)$ and the lowest mass of litter-fall is in the mature stand $\left(5794 \mathrm{~kg} \mathrm{ha}^{-1}\right)$. Similar situation is in case of needles (Fig. 2) and twigs (Fig. 5). On the contrary, at common oak leaves (Fig. 3) the highest mass of litter-fall is by mature stand. The highest differences between artificially and naturally regenerated stands are in case of total mass of litter-fall (Fig. 1) and in mass of associated woody species leaves (Fig. 4). Mass of litter-fall is higher in artificially regenerated stand. Slight differences with a higher proportion of litter-fall in naturally regenerated stand is in needle's fractions, common oak leaves, twigs and barks. Mass of litter-fall varies considerably during the year as is confirmed by high standard deviation by each fraction and section. 
The dynamic of litter-fall plays a significant role in carbon and nutrient cycle. The total annual litterfall was according to forest type in the range of 5794 $6588 \mathrm{~kg} \mathrm{ha}^{-1} \mathrm{y}^{-1}$. This finding is in agreement with Pavlenda \& Pajtík \& Priwitzer et al. (2012) finding. Increased litter-fall(up to $7000 \mathrm{~kg} \mathrm{ha}^{-1} \mathrm{y}^{-1}$ ) were reported by Gursky (1952), Kovalevsky (1952), Gorshenin, Shvidenko, (1977), Nakonechny (1978) and Ostapchuk (2012) in other forest areas. According to Bondar (2007), the annual mass of litter in pine-oak stands of fresh fairly fertile site type of Central Polissia of Ukraine is about $5200 \mathrm{~kg} \mathrm{ha}^{-1} \mathrm{y}^{-1}$, whereas for pine in Finland it ranged from 1325 to $3402 \mathrm{~kg} \mathrm{ha}^{-1} \mathrm{y}^{-1}$, what is caused by colder climate (Ukonmaanaho et al. 2008). There are even higher annual above ground litter production up to $11000 \mathrm{~kg} \mathrm{ha}^{-1} \mathrm{y}^{-1}$ in temperate deciduous forest (Gobat et al. 2004). This higher production of litter is caused by higher precipitation and warmer climate.

\section{Conclusion}

The formation of litter in the hornbeam-oak-pine stands in the Lviv Roztoche region occurs throughout the year.

In the annual dynamics of litter-fall mass in the hornbeam-oak-pine stands, two peaks can be observed: the highest one in October (mainly due to the falling of leaves and pine needles cast) and in May (mainly due to the falling of cones, twigs, pine needles, damaged young leaves of associate species). There were observed third peak during the winter months in the case of twig's and bark's fractions. This results correspond with findings in other part of temperate forest zones.

Based on the our results we can confirm hypotheses that in in the hornbeam-oak-pine stands of the Lviv Roztoche region are differences by litter-fall according to age of the stand and form of forest stand regeneration. In the middle-aged hornbeam-oak-pine stands, despite the lower growing stock, the annual mass of litter is larger than in mature stands. The annual litter mass in the artificial middle-aged hornbeam-oak-pine forest stands is greater than in the naturally regenerated stand. This results are not valid for all fraction of litter-fall. There is higher mass of litter-fall in mature stand in case of common oak leaves fraction. Similar slight differences with a higher proportion of litter-fall in naturally regenerated stand is in needle's, common oak leaves, twig's and bark's fraction.

\section{References}

Bodnar, I. P., 2000: Kil'kisni ta jakisni pokazniki opadu $\mathrm{v}$ riznich tipach umov miscezrostannja lisostaniv Kijivskogo Polissja tajich vplivna grunt. Lisivnicctvo, 27:94-103.
Bodnar, I. P., 2007: Biotičnij krugoobig mineral'nich elementiv ta šljachi jogo reguljuvannja v sosnovich derevostanach Central'nogo Polissja Ukrajini. L'viv, $20 \mathrm{p}$.

Bublinec, E., 1994:Koncentrácia, akumulácia a kolobeh prvkov v bukovom a smrekovom ekosystéme. Bratislava, VEDA, $132 \mathrm{p}$.

Fisher, R. F., Binkley, D., 2000: Ecology and management of forest soils. John Wiley \& Sons, New York, $489 \mathrm{p}$.

Gobat, J.-M., Aragno, M., Matthey, W., 2004:The Living Soil: Fundamentals of Soil Science and Soil Biology. Enfield, NH: Science Publishers.

Goršenin, M. M., 1972: Stacionarni doslidžennja vplivu riznich sposobiv postupovich rubok na umovi seredovisšča, produktivnist' derevostaniv i lisovidnovlennja. Zb. nauk.-techn. prac. L'viv, Kamenyar, p. 14-24.

Goršenin, N. M., 1977: Lesovodstvo. L'vov, Višča škola, $303 \mathrm{p}$.

Gurskij,V.V., 1952: Ob izmeneniivlažnosti počvogruntai oblistvenii dubai drugich porod včistych i sme šanych kul'turach. Tr. UkrNIILKHA, p. 37-41.

Hikitin, K., 1984: Sortimentnyje tablicy dlja taksacii lesa na kornju. Urozhay, 629 p. Kovalevs'kij, A. K., 1952: Ričnij vidpad listja v dibrovach.Pr. In-tu lisivnictva AN URSR, 3:21-24.

Kacálek, D., Dušek, D., Novák, J., Bartoš, J., 2013: The impact of juvenile tree species canopy on properties of new forest floor. Journal of Forest Science, 59:230 237.

Kremenecka, J.O., 2000: Lisivnickiosoblivosti korinnich lisostaniv zelenoji zoni m. Kijeva ta naukovi osnovi pokraščennja ichnogo stanu. Kijiv, 19 p.

Lukac, M., Godbold, D. L., 2011: Soil ecology in northern forests: a below gownd view of a changing world. Cambridge University press, New York, 256 p.

Melekhov, I. S., 1980: Lesovedeniye. Lesn. prom-st', 408 p.

Nakonečnyj, V. S., 1978: Vlijaniye sostava nasaždenij v dubrovach na ich produktivnost. Nauch. tr. USKHA. Ser. "Lesovodstvo i lesorazvedenije", 19:98-101.

Novák, K., Slodičák, M., Dušek, D., Kacálek, D., 2013: Noeway spruce litterfall and forest floor in the IUFRO thinning experiment CZ 13 - Vítkov. Journal of Forestr Science, 59:107-116.

Novák, K., Dušek, D., Slodičák, M., 2014: Quantity and Quality of litterfall in young oak stands. Journal of Forestr Science, 60:219-225.

Novák, K., Dušek, D., Slodičák, M., Kacálek, D., 2015: Opad v mladých borových porostech. Zprávy lesnického výzkumu, 60:115-121.

Ostapčuk,O.S., 2012:Lisovijopad tapidstilkavkul'turach duba zvičajnogo v umovach Pravoberežnogo Lisostepu. Nauk. visnik Nats. un-tu bioresursiv i prirodokoristuvannja Ukrajini. Vip., 171:186-192. 
Pavlenda, P., Pajtík, J., Priwitzer, T. et al., 2012: Monitoring lesov Slovenska. Správa za projekt FutMon a ČMS Lesy za rok 2011. Zvolen, NFC Zvolen, 132 p.

Peško, V. S., 1972: Dinamika vlastivostej dernovo-slabopidzolistich gruntiv Roztoččja u zvjazku z rubkami golovnogo koristuvannja. Lisivnicki doslidžennja na Roztočči, Zb. nauk.-techn. prac, p. 14-24.

Pogrebnjak, P.S., 1968: Obšee lesovodstvo. Kolos, 440 p. Remezov, N. P., 1953: O roli lesa v počvoobrazovani. Pochvovedeniye, 12.
Ribak, V. O., 2004: Vpliv mišanich lisostaniv na procesi gruntotvorennja u svižich sosnovich suborach. Nauk. visnik Nac. un-tu bioresursiv i prirodokoristuvannja Ukrajini, Vip., 71:27-33.

Sokolova, S., 1984: OST 56-69-83. Probnyje plošchadi lesoustroitel'nyje. Metod zakladki, $60 \mathrm{p}$.

Švidenko, A. I., 1987: Normativno-spravočnyje materialy dlja taksacii lesov Ukrainy i Moldovii. 558 p.

Ukonmaanaho, L., Merilä, P., Nöjd, P., Niemonen, T. M., 2008: Litterfall production and nutrient return to the forest floor in Scots pine and Norway spruce stands in Finland. Boreal Environment Research, 13 (suppl. B): 67-91. 